\author{
H. Khudov ${ }^{1}$, Salman Rashid Owaid ${ }^{2}$, V. Lishchenko ${ }^{1}$, V. Tiutiunnyk ${ }^{1}$ \\ ${ }^{1}$ Ivan Kozhedub Kharkiv National Air Force University, Kharkiv, Ukraine \\ ${ }^{2}$ Al Maaref University College, Ramadi, Iraq
}

\title{
METHODS OF SIGNAL PROCESSING IN A MULTIRADAR SYSTEM OF THE SAME TYPE OF TWO-COORDINATED SURVEILLANCE RADARS
}

The subject of research in the paper is the problem of developing methods of signal processing in a multiradar system of the same type of two-coordinate surveillance radars with mechanical rotation. The aim of the paper is to improve the quality of detection of air objects by combining the same type of two-coordinate radars in a multi-radar system. It is proposed to combine the existing surveillance radar stations into a spatially spaced coherent multiradar system. The synthesis of optimal detectors of coherent and incoherent signals is carried out. The characteristics of detection of air objects in a multi-radar system with compatible signal receiving have been evaluated. The obtained results: the addition of the second radar, regardless of the degree of signal coherence, showed the greatest efficiency in the gain in terms of signal / noise, the optimal number of radars in the multi-radar system is not more than four. The expected signal / noise threshold gain in a system of four radars can be up to eighteen decibels for a system with coherent signals and up to eleven decibels for a system with incoherent signals. The using of more than four radars is impractical.

Keywords: method, radar, multiradar system, signal processing, signal-to-noise ratio, mechanical rotation.

\section{Introduction}

Formulation of the problem in general. In the context of modern local armed conflicts, hostilities in eastern Ukraine, the construction of a reliable radar reconnaissance of airspace is significantly complicated by the appearance of inconspicuous (with low radar contrast) and small air objects [1-2].

From the experience of the Joint Forces operation in eastern Ukraine, it is known that small unmanned aerial vehicles (UAVs) in most cases were not detected by the available means of radar of radio troops [2-7], which form the basis of the air defence intelligence subsystem.

The world and domestic manufacturers of radar equipment implement the latest advances in science and technology: serial-parallel electronic survey of the area around the corner and two-dimensional electronic scanning of the antenna pattern, adaptive phased array antennas, digital synthesis of probe signals with different parameters, digital diagram [4-6].

Currently, the radar troops of the Air Force of the Armed Forces of Ukraine receive the latest and modernized models of radar, including broadband phase-lodged signals and digital phased array antennas, but this process is gradual and expensive. Therefore, in general, the existing equipment of the units does not provide a complete solution to the tasks assigned to the units, especially in the part relating to the detection of inconspicuous air object.

At the same time, the radio engineering units are armed with a large number of two-coordinate observation radars of the P-18 type and its numerous upgraded versions. These radars are not able to provide detection of modern inconspicuous air object with the specified quality indicators [5].

Thus, at present, in solving the problem of detecting inconspicuous air object, the discrepancy between the development trends of air object and the capabilities of existing radars to detect inconspicuous air object with the required efficiency has sharpened.

To solve this discrepancy and increase the efficiency of detection of inconspicuous air object, it is proposed to combine the existing two-coordinate survey radar into a coherent multi-radar system (MRS) with compatible signal processing [8-10].

The purpose of the paper - development of signal processing methods in a multiradar system of the same type of two-coordinate surveillance radars.

\section{Statement of basic materials}

\section{Analysis of recent achievements and publications}

To date, the tasks of search and detection of inconspicuous air object are solved by monitoring, using radio, and infrared, optical, acoustic and combined means of reconnaissance (Fig. 1).

Each of these methods has its advantages and disadvantages. The use of radar reconnaissance has its undeniable advantages over other methods [11-15]. In addition to the known methods of radar in recent years are developing and widely used non-traditional: the use of external sources of illumination, using the effect of "radar on the lumen", the use of passive-active radar systems and others. 


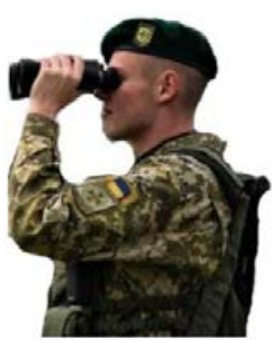

a) observer with optical device

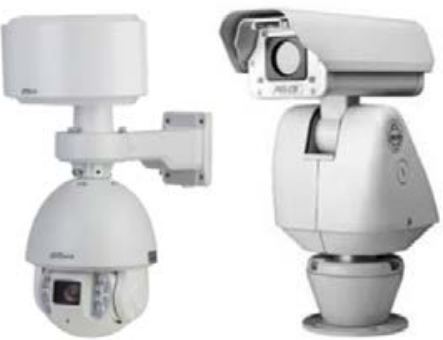

b) optoelectronic and thermal imaging cameras
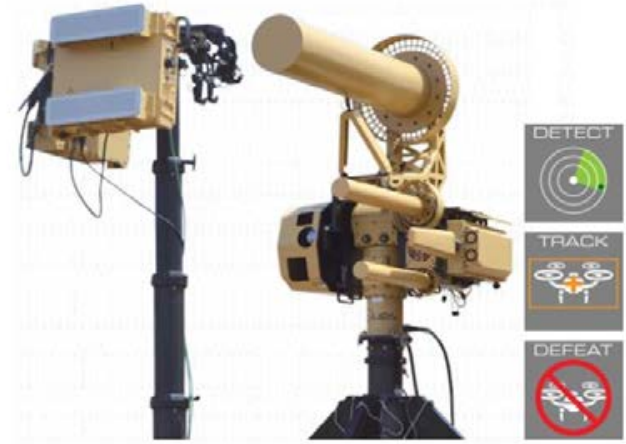

c) combined radar complex

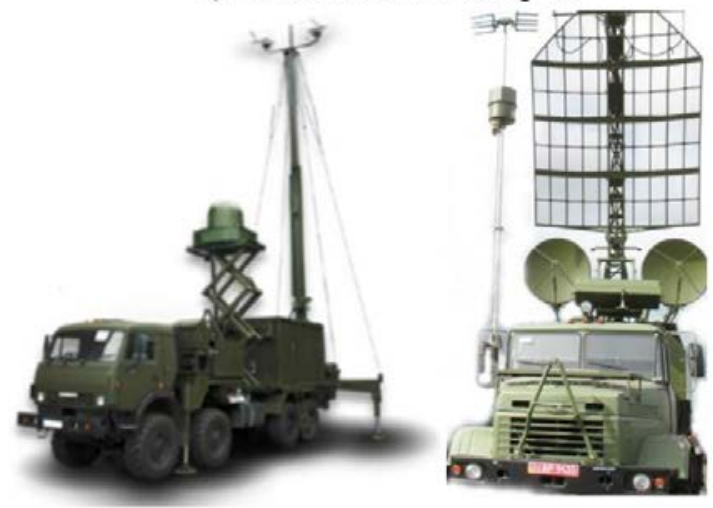

d) passive location stations

Fig. 1. Existing methods for detecting inconspicuous air objects

These methods are based on a general trend in the development of technology - the integration of individual devices (tools) into systems. It is known that there are a number of different types of multiradar systems. The individual positions of the elements of such systems are spatially spaced from each other, while the processing of radar information is carried out in a central processing point, which can be combined with one of the positions or located separately. At this point, it is advisable to carry out joint processing of radar information, the effectiveness of which depends on the degree of coherence provided in the system [11-14].

\section{Problem and presentation materials researching}

Creating of a multi-radar system makes it possible to solve the problem of increasing the energy potential of radar, increasing the gain of antenna systems or the use of system effects. The using of system effects when combining autonomous radars into a multi-radar system is associated with the possibility of implementing different degrees of coherence of spatially spaced positions and the combined reception of echoes [9-14]. The paper proposes to combine the existing survey two-coordinate radars into a synchronous multiradar system according to the method described in [8] and is explained by the algorithm shown in Fig. 2.

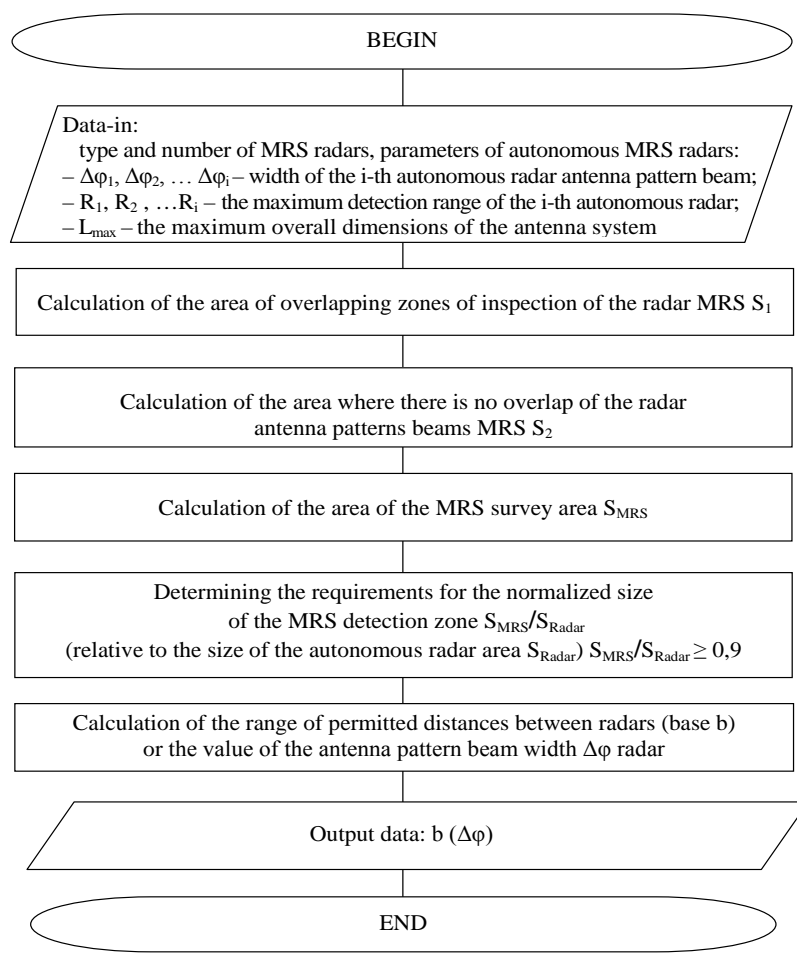

Fig. 2. Method of forming an agreed inspection area small base multiradar system of the same type surveillance radars

One of the key issues that determine the possibility of creating a synchronously coherent multi-radar system with spatially spaced radars is the need to meet the conditions:

- frequency synchronization;

- phase synchronization;

- time synchronization;

- coordinated overview of the space.

In Fig. 3 shows an example of building a multiradar system.

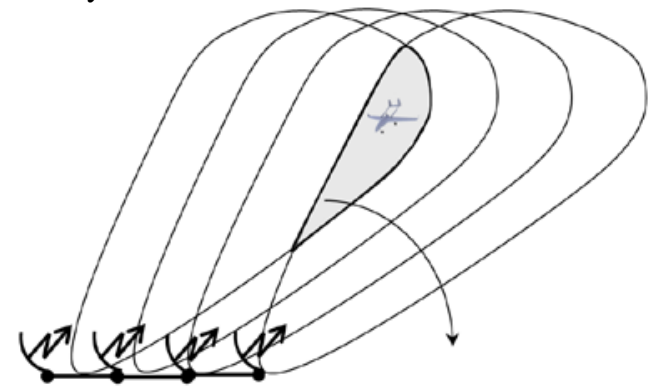

Fig. 3. Multi-radar system on the example of a synchronous small-base system with 4 radars 
Each of the radar emits its own transmitting signal, which is not correlated with the transmitting signal of other radars. The signals of all radars are emitted simultaneously. Non-correlation (orthogonality) can be provided by:

- frequency diversity (frequency);

- coding of signals (code).

Each radar receives echo signals:

- its transmitting signal reflected from the air object;

- reflected from the air object transmitting signal of neigh boring radars.

Depending on the construction of the synchronization system of the multiradar system, the signals emitted by the radar may be mutually coherent or incoherent. Therefore, in a multiradar system it is possible to implement methods of processing mutually coherent or mutually incoherent signals.

Method of processing coherent signals in a multiradar system.

Consider a multiradar system in which each radar emits mutually orthogonal signals. These signals are reflected from an air object of complex shape. If the size of the air object is much larger than the wavelength, the signals received by each radar fluctuate. As a rule, amplitude fluctuations are described by Rayleigh law, and phase fluctuations are evenly distributed in the interval $(-\pi, \pi)$. The nature of the fluctuations of the signals received by different radars depends on the degree of their spatial correlation, which is determined by the size of the effective base (distance) between the radar (expression (1)):

$$
\frac{L_{e f}}{R}>(0.8 \ldots 1) \frac{\lambda}{l_{A O}},
$$

where $L_{e f}=L \sin (\theta)$ - effective base between spatially spaced radars $(\theta-$ the angle that determines the direction of the air object);

$R$ - range to the air object from the middle of the effective base;

$\lambda$ - radar wavelength;

$l_{A O}$ - transverse size of the air object (parallel to the effective base).

At full spatial correlation, the complex amplitudes and initial phases of the signals at the inputs of different positions are strongly connected and fluctuate amicably. Therefore, such signals are spatially coherent. At small bases between receiving positions rigid communication between complex amplitudes of echo signals in various positions (full time correlation) is possible.

At the input of the radar receiver in each position receives signals emitted by all radar.

If all radars emit the same signals in such a way that their in-phase summation on the air object is ensured, then at the input of the receiving positions there will be only one echo signal. The effective value of the amplitude of the echo signal in this case will be equal to the sum of the effective values of the echo signals formed by all transmitting positions [11-16].

In this case, the processing is performed on $M$ implementations of independent Gaussian processes. The average value of these processes in each receiving position is equal to the phased sum of $\mathrm{M}$ echo signals. The initial value of the signal-to-noise is determined by expression (2):

$$
q_{\text {out }}^{2}=N M^{2} q_{\text {out } 0}^{2}
$$

where $q_{\text {out } 0}^{2}$ - signal-to-noise ratio at the output of a single-position radar;

$N$ - the number of radars operating in transceiver mode;

$M$-implementations of independent Gaussian processes.

The additional gain in $M$ times is explained by the fact that at in-phase addition of signals on air object noises of the receiver do not take part, and at coherent addition in receiving devices together with signals incoherent noise develops.

The method of processing coherent signals in a multiradar system of the same type of two-coordinate survey radars with mechanical rotation is proposed in the form shown in Fig. 4.

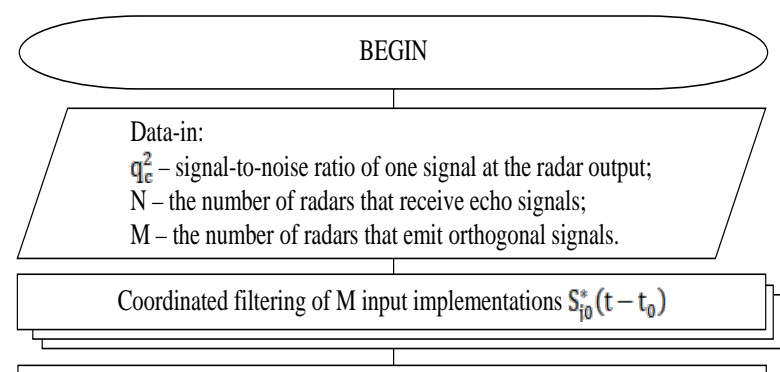

Compensation of phase shifts of each signal (related to the difference of distances from the elements of the multiradar system to the air object)

Coherent addition of signals from the outputs of coordinated filters $M$ signals at the output of the receiving system of each of the $\mathrm{N}$ radars from the system

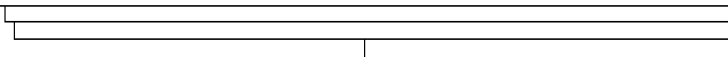

Quadratic detection of coherent adders outputs for signals of each type at the output of each of the $\mathrm{N}$ radars from the MRS

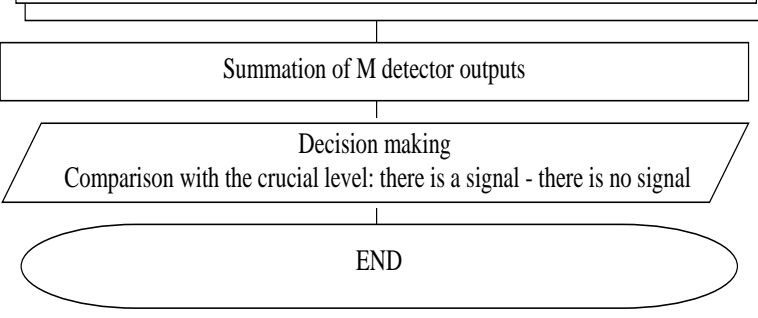

Fig. 4. Method of processing coherent signals in a multiradar system

In the case of coherent signal summation and linear detection, the original statistics has a Rayleigh 
distribution, and in the case of quadratic detection, it has an exponential probability distribution. To construct detection curves in both cases, it is convenient to use a known expression for the probability of correct detection and false alarm (expression (3)):

$$
P_{D}=P_{F}^{1 /\left(1+\overline{q_{\text {out }}^{2}}\right)},
$$

where $P_{D}$ - probability of correct detection;

$P_{F}$ - probability of false alarm;

$q_{\text {out }}^{2}$-signal-to-noise ratio at the input of a threshold device, which is determined depending on the features of the construction of a spatially coherent multiradar system.

In Fig. 5 shows the detection curves for a small base spatially coherent multiradar system.

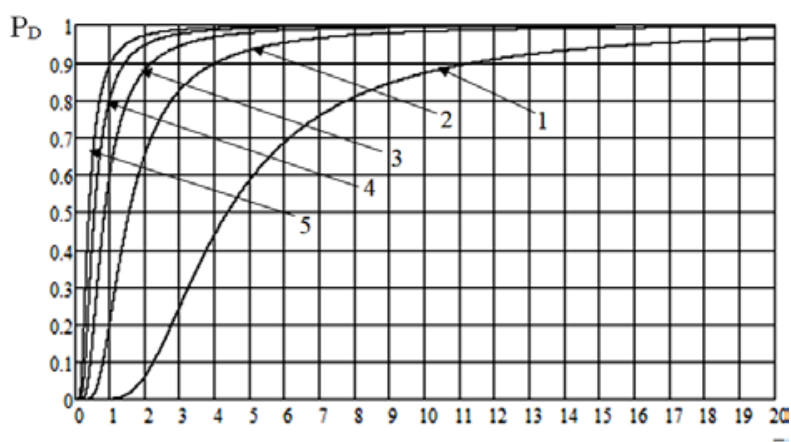

Fig. 5. Characteristics of detection of multiradar system: 1 - for autonomous radar;

2 - when using 2 radars in a multiradar system;

3 - when using 3 radars in a multiradar system;

4 - when using 4 radars in a multiradar system;

5 - when using 5 radars in a multiradar system

Fig. 5 shows the case when all the same type of radar small base spatial-coherent multiradar system uses the same signals so that their in-phase summation on the air object and at the input of the receiving positions we get only one echo signal. Calculations are given for the operation of one autonomous radar and for the use of a multiradar system with several radars for the probability of false alarm $P_{F}=10^{-6}$.

Method of processing incoherent signals in a multiradar system.

Consider the case where each of radars in the multiradar system has the ability to receive and process all signals emitted into the multiradar system. When radiating into a multiradar system mutually incoherent transmitting signal, but ensuring mutual coherence of receiving systems radar (due to the corresponding synchronization of the local oscillators of receiving systems) and mutual spatial correlation of fluctuations of echo signals from the air object (due to reducing the distance between radar) Pearson's detection algorithm looks like this:
$L=\sum_{i=1}^{M}\left|\sum_{j=1}^{N} \exp \left(j \omega_{0} \tau_{\text {rec } j}\right) \int_{-\infty}^{\infty} S_{i 0}^{*}\left(t-t_{0}\right) x_{j}(t) d t\right|_{\leq}^{2} h$,

where $\tau_{\text {rec } j}$ - taking into account the delay time of the transmitting signal emitted by the $i$-th radar in the receiving device of the $j$-th radar;

$S_{i 0}^{*}\left(t-t_{0}\right)$ - pulse characteristic of the matched filter of the signal emitted by the $i$-th radar;

$x_{j}(t)$ - the signal received in the receiving device of the $j$-th radar;

$N$ - the number of radars emitting orthogonal signals;

$M$ - the number of radars that receive echoes.

From the analysis of expression (4) we determine the sequence of actions (Fig. 6).

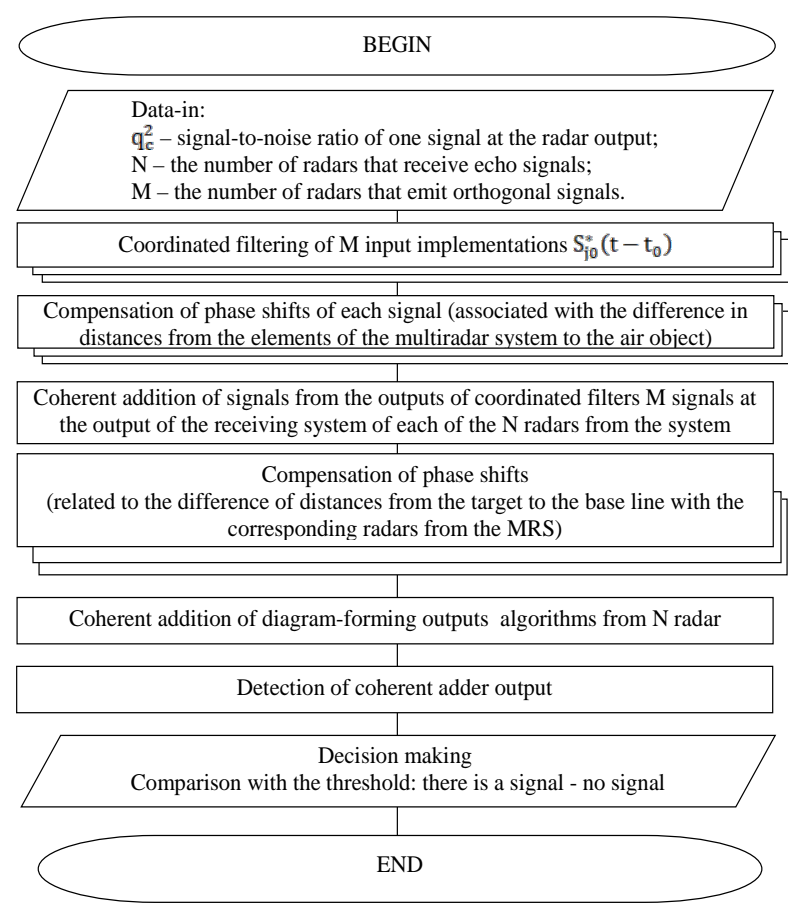

Fig. 6. Method of processing incoherent signals in a multiradar system

Let's analyse the quality of the method shown in Fig. 2. The initial statistics in the absence of a signal is determined by the expression:

$$
\begin{aligned}
& L_{0}=\sum_{i=1}^{\mathrm{M}}\left|\sum_{j=1}^{N} \exp \left(j \omega_{0} \tau_{\text {rec } j}\right) \int_{-\infty}^{\infty} S_{i 0}^{*}\left(t-t_{0}\right) n_{j}(t) d t\right|^{2}, \\
& =\sum_{i=1}^{M}\left|Z_{0 i}\right|^{2}
\end{aligned}
$$

where

$$
\begin{aligned}
& Z_{0 i}=\sum_{j=1}^{N} \exp \left(j \omega_{0} \tau_{\text {rec } j}\right) \int_{-\infty}^{\infty} S_{i 0}^{*}\left(t-t_{0}\right) n_{j}(t) d t \\
& \quad n_{j}(t) \text { - noise process in } j \text {-th radar. }
\end{aligned}
$$


Statistics $Z_{0 i}$ is a Gaussian random variable with zero mean, and the variance of statistics (6) is determined by the expression (7):

$$
\frac{1}{2} \overline{Z_{o i}^{*} Z_{o i}}=\sum_{j=1}^{N} N_{0} \int_{-\infty}^{\infty}\left|S_{i 0}^{*}(t)\right|^{2} d t=2 N_{0} N \tau_{i} .
$$

The calculation of the detection threshold for a given probability of false alarm is carried out by expression (8):

$$
h_{0}=F^{-1}\left(\frac{p}{v}\right)=\left\{h_{0}: F\left(\frac{h_{0}}{v}\right)=p\right\},
$$

where $h_{0}$ - threshold value for the probability of false alarm $P_{F}$;

$v=2 M-$ number of degrees of freedom;

$$
p=\left(1-P_{F}\right)=F\left(\frac{h_{0}}{v}\right)=\int_{0}^{h_{0}} \frac{t^{(v-2) / 2} e^{-t / 2}}{2^{\frac{v}{2}} \Gamma(v / 2)} d t ;
$$

$\Gamma(\cdot)$ - Gamma function.

Taking into account the orthogonality of the signals and the independence of random fluctuations in the amplitudes of the signals and the natural noise of the receiving channels, the average value of the signal-tonoise ratio at the detector input taking into account (7) is as shown in expression (10):

$$
\overline{q_{\text {incoh }}^{2}}=\frac{\frac{1}{2} \overline{Z_{1 i s}^{*} Z_{1 i s}}}{\frac{1}{2} \overline{Z_{o}^{*} Z_{o}}}=\frac{2 \overline{E_{s}} N^{2} \tau_{i}}{2 N_{0} \tau_{i} N}=\frac{N \overline{E_{s}}}{N_{0}}=N \overline{q_{s}^{2}},
$$

where $\overline{q_{\text {incoh }}^{2}}$ - the average signal-to-noise ratio at the detector input for a signal of the same type;

$$
\overline{E_{s}} \text { - the average energy of one signal at the input }
$$
of the receiving system of each of radars;

$\overline{q_{s}^{2}}$ - the average signal-to-noise ratio of a signal of the same type at the output of single radar.

From the analysis of expression (10) it is seen that the coherent summation of signals of the same type at the radar outputs with incoherent noise summation provides an increase in the signal-to-noise ratio at the detector input by $N$ times relative to the signal-to-noise ratio at each of radars.

For the case when the average signal-to-noise ratio is the same for all $M$ signals, the dependence of the probability of correct detection is determined by expression (11):

$$
P_{D} \approx\left(1+\frac{1}{M \overline{q_{\text {incoh }}^{2}}}\right)^{M-1} \exp \left[-\frac{h_{0} / 2}{1+M \overline{q_{\text {incoh }}^{2}}}\right],
$$

where $h_{0}$ - normalized threshold determined by a given level of false alarm according to the expression (8);
$M$ - the number of signals that are summed incoherently.

The detection characteristics for a single radar and a small-base multiradar system that implements the detection method according to algorithm (4) for the case when each radar receives incoherent signals of all radars from the multiradar system with a probability of false alarm $P_{F}=10^{-6}$ are shown in Fig. 7 .

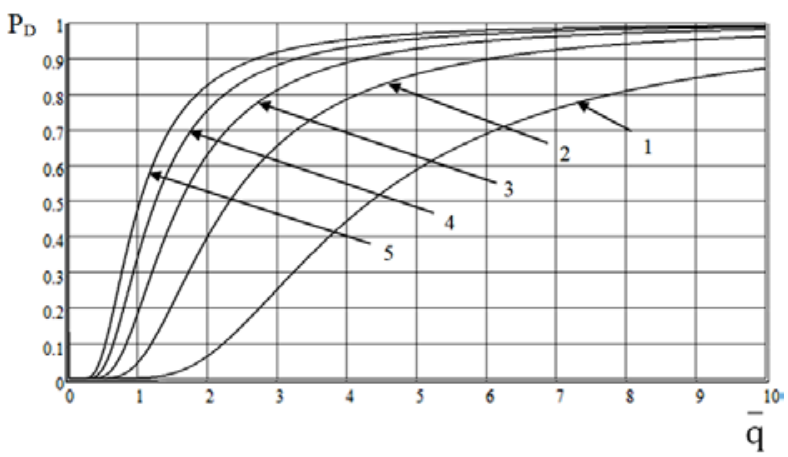

Fig. 7. Characteristics of detection of incoherent multiradar system that implements the method (Fig. 6), with a probability of false alarm $P_{F}=10^{-6}$ : 1 - for autonomous radar;

2 - when using 2 radar in a multiradar system;

3 - when using 3 radars in a multiradar system;

4 - when using 4 radars in a multiradar system;

5 - when using 5 radars in a multiradar system

From the analysis of the detection characteristics shown in Fig. 5, 7 shows that the transition from a stand-alone radar (curve 1) to a combination of two or three radars (curves 2, 3) leads to a significant shift in the detection characteristics to the left. Increasing the number of coherently combined radars by more than three (curves 4,5 ) does not lead to a significant shift in the detection characteristics to the left compared to the detection characteristics when combining three radars (curve 3).

In Fig. 8 shows the dependence of the win $K(m)$ in the desired signal-to-noise ratio in a system with $m$ radar relative to a stand-alone radar to ensure quality indicators of air object detection $\left(P_{D}=0,5, P_{F}=10^{-6}\right)$ for coherent (curve 1) and incoherent (curve 2) combining radars from the number of radars (m) combined.

$\mathrm{K}(\mathrm{m})$

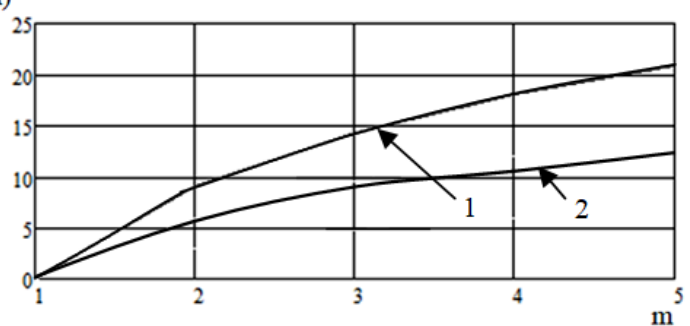

Fig. 8. Dependence of winnings in relation signal-to-noise in a multiradar system in the case when all radars use orthogonal signals:

1 - for coherent signals; 2 - for incoherent signals 
From the analysis of the dependence of the gain in the signal / noise ratio, shown in Fig. 8, it is seen that for the case when all the same type of radar small base spatially coherent multiradar system uses the same signals, a gain of about $10 \mathrm{~dB}$ when combining two radars, and about $5 \mathrm{~dB}$ with the addition of a third radar, and increase the gain by only $2.5 \mathrm{~dB}$ with the addition of a fourth radar and more radar also provide an increase in gain, but the rate of this growth is much slower, which impairs the practical significance and economic feasibility. So, summarizing the above, we can conclude that the greatest efficiency in the signal-to-noise gain when combining the same spatially distributed radar into a multiradar system is observed in the transition from one stand-alone radar to a multiradar system with two or three radars. A further increase in the number of radars in each of the two cases is accompanied by a decrease in efficiency from the addition of each subsequent radar and it is almost impractical to use in a multiradar system more than four radars with a maximum possible gain of close to $2 \mathrm{~dB}$ with the addition of the last radar from one radar to a multiradar system with two radars.

The addition of a second radar for the processing of coherent and incoherent signals showed the greatest efficiency in the gain in terms of signal / noise and all cases showed the optimal number of radars in the multiradar system not more than four.

Therefore, according to the efficiency-cost criterion, the most effective is to create a spatially coherent multiradar system by combining two to four identical radars.

Thus, to improve the quality of detection of incon- spicuous air object, it is advisable to create a spatially coherent multiradar system by combining two to four survey radars. In this case, the expected gain in the signal-to-noise ratio can be up to $18 \mathrm{~dB}$. The use of more than four radars is impractical, as it does not lead to a significant increase in gain.

\section{Conclusion}

Thus, it can be argued that the greatest gain in terms of signal / noise showed the addition of second radar to the system and the optimal number of radars in a multiradar system is not more than four. Therefore, according to the quality-cost criterion, the most effective is the creation of a spatially coherent multiradar system, but even in the case of processing incoherent signals, there will be an effect in improving the quality of detection of air objects. Thus, to improve the quality of detection of inconspicuous air object, it is advisable to create a spatially spaced small base synchronous multiradar system by combining two to four survey radars. The use of more than four radars is impractical, as it does not lead to a significant increase in winnings. The expected gain in the threshold signal / noise ratio when using the proposed methods of signal processing can be up to $18 \mathrm{~dB}$ (for the case of processing of coherent signals). The use of more than four radars is impractical, as it does not lead to a significant increase in gain. The direction of further research is to consider methods for determining the height of the air object in the case of using spatially spaced two-coordinate radars as elements of a synchronous small-base multiradar system with compatible signal processing.

\section{References}

1. Banasik, M. (2015), How to understand the Hybrid War,Securitologia, No. 1, pp. 19-34.

2. Alimpiiev, A.M. and Pievtsov, H.V. (2017), "Osoblyvosti hibrydnoi viiny RF proty Ukrainy. Dosvid, shcho otrymanyi Povitrianymy Sylamy Zbroinykh Syl Ukrainy” [The features of the hybrid war of the Russian Federation against Ukraine. Experience received by the Armed Forces of the Armed Forces of Ukraine], Science and Technology of the Air Force of Ukraine, No. 2(27), pp. 19-25. https://doi.org/10.30748/nitps.2017.27.03.

3. Hill, D. and Galloway, P. (2017), Multi-Static Primary Surveillance Radar - An examination of Alternative Frequency Bands, Report of EUROCONTROL, Issue 1.2, 183 p. Available at: www.eurocontrol.int/sites/default/files/content/documents/ $\mathrm{nm} / \mathrm{mspsr}$ study report. pdf (accessed 21 September 2017).

4. Lishchenko, V., Chaliy, V., Khudov, H. and Zvonko, A. (2018), Proposals for Improving of Air Surveillance Informativity in MIMO Radar Systems Based on Two-Dimensional Radars, IEEE 5 International scient.-pract. confer. Problems of Infocommunications. Science and Technology (PIC S\&T), pp. 153-156. https://doi.org/10.1109/INFOCOMMST.2018.8632052.

5. Khudov, H., Zvonko, A., Kovalevskyi, S., Lishchenko, V. and Zots, F. (2018), Method for the detection of small sized air objects by observational radars, Eastern-European Journal of Enterprise Technologies, No. 2/9(92), pp. 61-68. https://doi.org/10.15587/1729-4061.2018.126509.

6.Lishchenko, V., Khudov, H., Tiutiunnyk, V., Kuprii, V., Zots, F. and Misiyuk, G. (2019), The Method of Increasing the Detection Range of Unmanned Aerial Vehicles In Multiradar Systems Based on Surveillance Radars, IEEE 39th International Conference on Electronics and Nanotechnology (ELNANO), pp. 559-562. https://doi.org/10.1109/ ELNANO.2019.8783263.

7.Lishchenko, V., Kalimulin, T., Khizhnyak, I. and Khudov, H. (2018), The Method of the organization Coordinated Work for Air Surveillance in MIMO Radar, 2018 International Conference on Information and Telecommunication Technologies and Radio Electronics (UkrMiCo), Odessa, Ukraine, pp. 1-4. https://doi.org/10.1109/UkrMiCo43733.2018.9047560.

8.Lishchenko, V., Khudov, H., Lisogorsky, B., Baranik, O., Holovniak, D. and Serdjuk, O. (2020), The MIMO System on Based Existing Mechanical Rotation Radars with Wide Surveillance Area, 2020 IEEE 40th International Conference on Electronics and Nanotechnology (ELNANO), Kyiv, Ukraine, pp. 625-628. https://doi.org/10.1109/ELNANO 50318.2020.9088746.

9.Khudov, H., Lishchenko, V., Hyshko, H., Polonskyi, Y., Khizhnyak, I. and Riabukha, B. (2020), The MIMO Surveillance Radars System with High Accuracy Finding 2D Coordinates, International Journal of Emerging Trends in Engineering Research, No. 8(5), pp. 2026-2030. 2020. https://doi.org/10.30534/ijeter/2020/91852020. 
10. Khudov, H., Lishchenko, V., Lanetskii, B., Lukianchuk, V., Stetsiv, S. and Kravchenko, I. (2020), The coherent signals processing method in the multiradar system of the same type two-coordinate surveillance radars with mechanical azimuthal rotation, International Journal of Emerging Trends in Engineering Research, No. 8(6), pp. $2624-2630$. https://doi.org/10.30534/ijeter/2020/66862020.

11. Ruban, I., Khudov, H., Lishchenko, V., Zvonko, A., Glukhov, S., Khizhnyak, I., Maliuha, V., Polonskyi, Y. and Kushpeta, R. (2020), The Calculating Effectiveness Increasing of Detecting Air Objects by Combining Surveillance Radars into The Coherent System, IJETER, Vol. 8, No. 4, pp. 1295-1301. https://doi.org/10.30534/ijeter/2020/58842020.

12. Khudov, H., Kovalevskyi, S., Irkha, A., Lishchenko, V., Serdiuk, O. and Zots, F. (2019), The Proposals for Synchronization Positions of MIMO Radar System on the Basis of Surveillance Radars, Intern. Scient.-Pract. Conf. Problems of Infocommunications. Science and Technology (PIC S\&T), pp. 547-551. https://doi.org/10.1109/PICST 47496.2019.9061284.

13. Chernyak, V.S. (1998), Fundamentals of Multisite Radar Systems, Gordon and Breach Science Publishers, 475 p. https://doi.org/10.1201/9780203755228.

14. Skolnik, Merill I. (2008), Radar Handbook, Third Edition, USA: McGraw-Hill, 1351 p.

15. Chernyak, V.S. (2009), "O novom napravlenyy v radyolokacyy” [About a new direction in radar], Applied electronics, No. 4(8), pp. 477-489.

16. Willis, Nicholas J. and Griffiths, Hugh D. (2007), Advances in Bistatic Radar, SciTech Publishing Inc., 515 p.

\section{Список літератури}

1.Banasik M. How to understand the Hybrid War / M. Banasik // Securitologia. - 2015. - № 1. - P. 19-34.

2.Алімпієв А.М. Особливості гібридної війни РФ проти України. Досвід, що отриманий Повітряними Силами Збройних Сил України / А.М. Алімпієв, Г.В. Пєвцов // Наука і техніка Повітряних Сил Збройних Сил України. - 2017. № 2(27). - C. 19-25. https://doi.org/10.30748/nitps.2017.27.03.

3.Hill D. Multi-Static Primary Surveillance Radar - An examination of Alternative Frequency Вands [Електронний pecypc] / Dave Hill, Philip Galloway // Report of EUROCONTROL - 2017. - Issue 1.2. - 183 р. - Режим доступу: http://www.eurocontrol.int/sites/default/files/ content/documents/nm/mspsr study report. pdf.

4.Proposals for Improving of Air Surveillance Informativity in MIMO Radar Systems Based on Two-Dimensional Radars / V. Lishchenko, V. Chaliy, H. Khudov, A. Zvonko // IEEE 5 International scient.-pract. confer. Problems of Infocommunications. Science and Technology (PIC S\&T), - 2018. - P. 153-156. https://doi.org/10.1109/INFOCOMMST.2018.8632052.

5. Method for the detection of small sized air objects by observational radars / H. Khudov, A. Zvonko, S. Kovalevskyi, V. Lishchenko, F. Zots // Eastern-European Journal of Enterprise Technologies. - 2018. - № 2/9(92). - pp. 61-68. https://doi.org/10.15587/1729-4061.2018.126509.

6.The Method of Increasing the Detection Range of Unmanned Aerial Vehicles In Multiradar Systems Based on Surveillance Radars / V. Lishchenko, H. Khudov, V. Tiutiunnyk, V. Kuprii, F. Zots, G. Misiyuk // IEEE 39th International Conference on Electronics and Nanotechnology (ELNANO). - 2019. - P. 559-562. https://doi.org/10.1109/ ELNANO.2019.8783263.

7. The Method of the Organization Coordinated Work for Air Surveillance in MIMO Radar / V. Lishchenko, T. Kalimulin, I. Khizhnyak, H. Khudov // 2018 International Conference on Information and Telecommunication Technologies and Radio Electronics (UkrMiCo'2018): International confer., September, 10-14, 2018: thesis of reports. - Odessa, 2018. - P. 1-4. https://doi.org/10.1109/UkrMiCo43733.2018.9047560.

8.The MIMO System on Based Existing Mechanical Rotation Radars with Wide Surveillance Area / V. Lishchenko, H. Khudov, B. Lisogorsky, O. Baranik, D. Holovniak, O. Serdjuk // 2020 IEEE 40th International Conference on Electronics and Nanotechnology (ELNANO). - Kyiv, Ukraine. - P. 625-628. https://doi.org/10.1109/ELNANO 50318.2020.9088746.

9.The MIMO Surveillance Radars System with High Accuracy Finding 2D Coordinates / H. Khudov, V. Lishchenko, H. Hyshko, Y. Polonskyi, I. Khizhnyak, B. Riabukha // International Journal of Emerging Trends in Engineering Research. 2020. - № 8(5). - P. 2026-2030. https://doi.org/10.30534/ijeter/2020/91852020.

10. The coherent signals processing method in the multiradar system of the same type two-coordinate surveillance radars with mechanical azimuthal rotation / H. Khudov, V. Lishchenko, B. Lanetskii, V. Lukianchuk, S. Stetsiv, I. Kravchenko // International Journal of Emerging Trends in Engineering Research. - 2020. - № 8(6). - P. 2624-2630. https://doi.org/10.30534/ijeter/2020/66862020.

11. The Calculating Effectiveness Increasing of Detecting Air Objects by Combining Surveillance Radars into The Coherent System / I. Ruban, H. Khudov, V. Lishchenko, A. Zvonko, S. Glukhov, I. Khizhnyak, V. Maliuha, Y. Polonskyi, R. Kushpeta // IJETER. - 2020. - Vol. 8, № 4. - P. 1295-1301. https://doi.org/10.30534/ijeter/2020/58842020.

12. The Proposals for Synchronization Positions of MIMO Radar System on the Basis of Surveillance Radars / H. Khudov, S. Kovalevskyi, A. Irkha, V. Lishchenko, O Serdiuk, F. Zots // Intern. Scient.-Pract. Conf. Problems of Infocommunications. Science and Technology (PIC S\&T). - 2019. - P. 547-551. https://doi.org/10.1109/PICST 47496.2019.9061284.

13. Chernyak V.S. Fundamentals of Multisite Radar Systems / V.S. Chernyak. - Gordon and Breach Science Publishers, 1998. - 475 p. https://doi.org/10.1201/9780203755228.

14. Radar Handbook. Third Edition / editor in chief, Skolnik Merill I. - USA: McGraw-Hill, 2008. - 1351 p.

15. Черняк В.С. О новом направлении в радиолокации / В.С. Черняк // Прикладная радиоэлектроника. - 2009. №4(8). - C. 477-489.

16. Advances in Bistatic Radar / edited by Nicholas J. Willis, Hugh D. Griffiths. - SciTech Publishing Inc., 2007. - 515 p. 
Відомості про авторів:

Худов Геннадій Володимирович

доктор технічних наук професор

начальник кафедри Харківського національного

університету Повітряних Сил ім. І. Кожедуба,

Харків, Україна

https://orcid.org/0000-0002-8269-0089

Оваід Сальман Рашід

кандидат технічних наук,

Коледж університету Аль Мареф,

Рамаді, Ірак

https://orcid.org/0000-0002-1189-9707

\section{Ліщенко Віталій Миколайович}

ад’юнкт Харківського національного університету

Повітряних Сил ім. І. Кожедуба,

Харків, Україна

https://orcid.org/0000-0002-8269-0089

\section{Тютюнник Владислав Олександрович} кандидат технічних наук старший науковий співробітник начальник науково-дослідного відділу

Харківського національного університету

Повітряних Сил ім. І. Кожедуба,

Харків, Україна

https:/orcid.org/0000-0002-7766-3246
Information about the authors:

\section{Hennadii Khudov}

Doctor of Technical Science Professor

Head of Department of Ivan Kozhedub Kharkiv

National Air Force University,

Kharkiv, Ukraine

https://orcid.org/0000-0002-3311-2848

Salman Rashid Owaid

Candidate of Technical Sciences (PhD),

of Al Maaref University College,

Ramadi, Iraq

https://orcid.org/0000-0002-1189-9707

\section{Vitaliy Lishchenko}

Doctoral Student of Ivan Kozhedub Kharkiv

National Air Force University,

Kharkiv, Ukraine

https://orcid.org/0000-0002-8269-0089

Vladyslav Tiutiunnyk

Candidate of Technical Science Senior Research

Chief of Scientific Research Department

of Ivan Kozhedub Kharkiv National

Air Force University,

Kharkiv, Ukraine

https://orcid.org/0000-0002-7766-3246

\title{
МЕТОДИ ОБРОБКИ СИГНАЛІВ У МУЛЬТИРАДАРНІЙ СИСТЕМІ ОДНОТИПНИХ ОГЛЯДОВИХ ДВОКООРДИНАТНИХ РАДІОЛОКАЦІЙНИХ СТАНЦІЙ
}

\author{
Г.В. Худов, Оваід Сальман Рашід, В.М. Ліщенко, В.О. Тютюнник
}

Предметом дослідження в статті є завдання розробки методів обробки сигналів в мультирадарній системі однотипних оглядових двокоординатних радіолокаційних станцій з механічним обертанням. Метою роботи є підвищення якості виявлення повітряних малорозмірних та малопомітних (з малим радіолокачійним контрастом) об'єктів за рахунок об'єднання однотипних двокоординатних радіолокаиійних станиій у мультирадарну систему. Пропонується об'єднати існуючі оглядові двокоординатні радіолокачійні станції з механічним обертанням у азимутальній площині в просторово рознесену мультирадарну систему з можливістю реалізаиії когерентної обробки сигналів. Важливим питанням функиіонування мультирадарної системи виходячи з необхідності забезпечення сумісної обробки сигналів в реальному масштабі часу є забезпечення узгодженого огляду повітряного простору, яке вирішується синхронним обертанням елементів у малобазовій системі. Виконано синтез оптимальних виявлювачів когерентних $і$ некогерентних сигналів. Проведено оиінку характеристик виявлення повітряних об'єктів у мультирадарній системі з сумісним прийомом сигналів. Отримано наступні результати: додавання другої радіолокаційної станиії в систему, незалежно від ступеня когерентності сигналів, показало найбільший виграш у відношенні сигнал-щум, а оптимальна кількість радіолокаційних станиій в мультирадарній системі складає не більше чотирьох. Очікуване максимальне збільшення відношення сигналшум, шео може бути отримане в системі з чотирьох радіолокачійних станцій, за розрахунками буде складати до вісімнадияти децибел для системи з когерентними сигналами і до одинадияти децииел для системи з некогерентними сигналами. Використання більи чотирьох радіолокаційних станцій у мультирадарній системі такого типу недоиільно тому, що подальще збільшення кількості елементів не призводить до суттєвого підвищення виграшу.

Ключові слова: метод, радіолокачійна станиія, мультирадарна система, обробка сигналів, відношення сигналшум, механічне обертання.

\section{МЕТОДЫ ОБРАБОТКИ СИГНАЛОВ В МУЛЬТИРАДАРНОЙ СИСТЕМЕ ОДНОТИПНЫХ ОБЗОРНЫХ ДВУХКООРДИНАТНЫХ РАДИОЛОКАЦИОННЫХ СТАНЦИЙ}

\author{
Г.В. Худов, Оваид Сальман Рашид, В.Н. Лищенко, В.А. Тютюнник
}

Предметом исследования в статье является задача разработки методов обработки сигналов в мультирадарной системе однотипных обзорных двухкоординатных радиолокачионных станиий с механическим вращением. Целью работы является повышение качества обнаружения воздушных объектов за счёт объединения однотипных двухкоординатных радиолокационных станций в мультирадарную систему. Предлагается объединить существуюшие обзорные радиолокаиионные станции в пространственно разнесённую когерентную мультирадарную систему. Выполнен синтез оптимальных обнаружителей когерентных и некогерентных сигналов. Оиенены характеристики обнаружения воздушных объектов в мультирадарной системе с совместным приёмом сигнала. Получены результаты: добавление второй радиолокационной станции, независимо от степени когерентности сигнала, показало наибольший выцгрыш в отношении сигнал-иум, оптимальное количество радиолокационных станиий в мультирадарной системе - не более четырех. Ожидаемое предельное увеличение отношения сигнал-иум в системе из четырех радиолокационных станций может составлять до восемнадиати дечибел для системы с когерентными сигналами и до одиннадиати дечибел для системы с некогерентными сигналами. Использование более четырех радиолокационных станций нецелесообразно.

Ключевые слова: метод, радиолокачионная станция, мультирадарная система, обработка сигналов, отношение сигнал-иум, механическое вращение. 